\title{
Classification of Morbidity (Nosology) - Understanding and interpretations from Ayurveda and Biomedicine
}

\section{Review article}

\author{
Saketh Ram T ${ }^{1}$, Srinivasulu B $^{2}$, Manohar Gundeti ${ }^{4}$, Narayana $\mathrm{A}^{3}$ \\ 1.Research Officer (Ayu), 2. Senior Research Fellow, 3. Director, \\ National Institute of Indian Medical Heritage (NIIMH), $3{ }^{\text {rd }}$ Floor, \\ OMC Building, Putlibowli, Hyderabad 500095; \\ 4. Research Officer (Ayu), RRAPACRI, Worli, Mumbai.
}

\begin{abstract}
The term Nosology refers to the science of classification of disease. Developments in area represent heterogeneous process spanning across long timelines and geographical areas. Descriptions of Classification of disease are well documented in Ayurveda codified texts and presents compact classification methodology from the very division of medical specialties in to 8 types (Ashtangas) which include kayacikitsa (general medicine), Shalya (surgery), Shalakya (ear, nose, throat, dental and diseases of head), Balaroga (Pediatrics), etc., The same is followed for the categorization of diseases too. Apart from this the basis of understanding diseases is pathophysiological (dosha-dhatu-mala) and the analysis is based up on Triskandha (three arms) 1. Hetu (cause), 2. Linga (presentation) and 3. Aushadha (suitable regimen). This is a distinct feature which carves out a niche for Ayurveda in terms of Nosological advantage. Greeco roman medicine started documenting classification of diseases from $16^{\text {th }}$ century The events showcase a transition from Magical remedies to Biographical approach and finally to the Nosological approach which has finally lead to the development of International classification of Disease (ICD). Currently ICD-9 is is implemented and it is now heading for a major revision with ICD-10. This is going to be Operational from the year 2014 and likely to be followed by another major revision ICD-11 (to include standard terminology of some of the alternative medical systems like Chinese and Korean medicine.). An attempt is made in this article to document the chronicle of developments which has led to current International Classification of Diseases (ICD).
\end{abstract}

Keywords: Diseases classification, Nosological approach, interpretations of Ayurveda, Biomedicine, ICD-10

*Corresponding author:

\section{Dr. T. Saket Ram}

Research Officer,

National Institute of Indian Medical

Heritage, Osmania Medical College

Building, Putlibowli,

Hyderabad - 500095

E-mail: dr.saketram@gmail.com,

Ph.No: 9849995719

\section{Definition:}

The term Nosology refers to the science of description and classification of disease. Disease is an abnormal condition affecting the body of an organism. In humans, "Disease" is often used more broadly to refer to any condition that causes pain, dysfunction, distress, social problems, and/or death to the person afflicted or similar problems for those in contact with the person.(1) 
Medical coding can be defined as the process of assigning numeric or a combination of numeric and alpha values to all types of medical services (diagnoses, medical procedures, surgery, drugs and other treatments). (2)

Development of Nosography (preparatory phase of nosology) across various medical disciplines of the world is a very heterogeneous process, and includes remote time lines and diverse geographical areas. For instance we find an independent, nearly evolved nosological arrangement of diseases in Ayurveda, with clear distinction between disease based on etiology, involvement of tissues (Dhatu), channels (Srotas) and the region of the body. The classification has evolved to such an extent that it considers the conditions which are congenital in nature, conditions due to abnormal ovum and sperm (indicating genetic conditions), diseases due to injury (Adhibhautika). The method of enumeration of each disease with its subtypes, and distinction between manageable (Sadhya) and difficult to manage having very bad prognosis (Asadhya) is another proof of mature medical nosological thinking in Ayurveda. The hall mark of feature of Ayurveda which is its holistic approach is appreciated when it advocated the use of Dashavidha pariksha (ten fold diagnosis) which lays emphasis on collecting every details pertaining to the individual bring the focus on the individual biography, providing links to his/her disease. In doing so, Ayurveda never lost track to understand the nature, strength of nature, and finally advocates treatment taking both (biography and nosography) into consideration.

On the contrary, the western medicine especially in Greeco-roman medicine we find a transition from Magical remedies to Biographical approach and finally to the nosological approach which has finally lead to the development of current Biomedicine.
Understanding this subject is of utmost important as we are now heading for a major revision of ICD-10, which is going to be functional from the year 2014, which is followed by another major revision ICD-11, which is going to include standard terminology of some of the alternative medical systems like Chinese and Korean medicine.

An attempt is made in this to document the chronicle of developments which has led to current International Classification of Diseases (ICD) and also provides glimpses of concept of disease and attempts to provide amicable classifications from Ayurveda.

\section{Approach to disease classification in Ayurveda:}

"Ayurveda" the Upaveda of Atharavana veda has dealt in detail with the human health and disease. The very objective of this applied Vedic discipline is maintenance of health of the healthy and provide succor to the suffering of the ailing. The approach is far more evolved and is very much holistic in nature. Unlike then western medicine where it took almost 1500 years to make a transition from Natural History method (Hippocratic $\begin{array}{llll}\text { approach } & 4 & \text { AD) }\end{array}$ Pathographic/Nosographic approach (Sydenham $16^{\text {th }}$ Century). Ayurveda has the advantage of having advantage of codified texts and presents the description of tight classification methodology from the very classification of medical specialties in to 8 types (Ashtangas) which include the specializations like Kayacikitsa (general medicine), Shalya (surgery), Shalakya (ear, nose, throat, dental and diseases of head), Balaroga (pediatrics), etc., which obviously have followed the same spirit into categorization of diseases too. Apart from this the basis of disease understanding is Pathophysiological (Dosha-dhatu-mala) and the analysis based up on Triskandha (three arms) 1. Hetu (cause), 2. Linga (presentation) and 
3. Aushadha (suitable regimen). The broad scheme for therapeutic classification of diseases is as follows:

1. Yuktivyapashraya: Management of disease based on thorough pathophysiological and suitable pharmaco therapeutic approach and laid emphasis on strict adherence to nosography (depiction of disease presentation in a structured manner).

2. Satvavajaya (mental mapping and understanding persons psyche): It provides basis for biographic (detailed personal history recording and counseling) approach.

3. Daivavyapashraya: It is interesting to find out that the third dimension, magico-remedial approaches (Daivavyapashraya- Mani, Mangala, Homa etc.,) were reserved for managing large scale epidemics where community participation is expected and were by and large meant for evacuations or self containing quarantining systems to prevent the further spread of the epidemic.

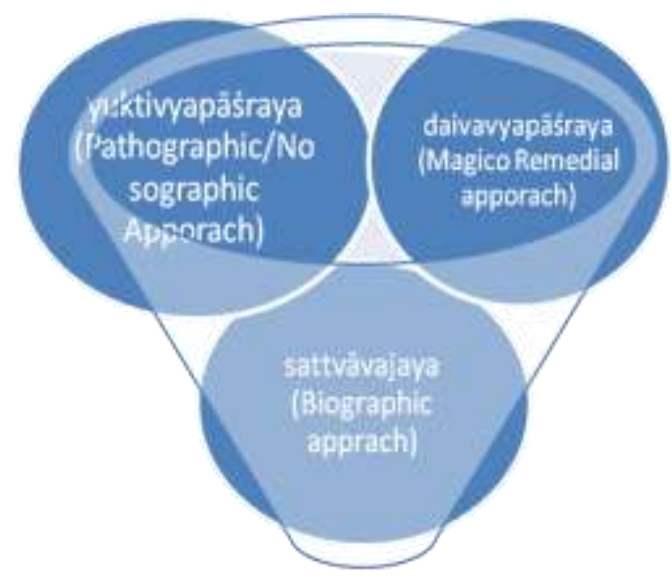

Understanding of Disease and the Diseased

Figure No: 1
1. The Ayurvedic term for disease is roga. It has also been called vyadhi, atanka, vikara, gada and duhka. Every living being has three aspects, the body mind and soul. Of these three, only body and mind are the abodes of disease (ca. su. 1/43). (3)

Synonyms of the disease in Sanskrit represent a wide variety of expressions and provide the glimpse of Physiological, pathological, biographical, nosological background for the same. Some of the widely known synonyms are as follows: Roga (which gives pain), Papma (a disease caused due to sinful acts), Jvara (because it torments), Vyadhi (it brings in different kinds disorders), Vikara (it brings in different kinds of abnormalities it causes various kinds), Duhkha (it causes various kinds of sadness), Amaya (it is caused by Ama), Yakshma (means few symptoms together indicate a disease), Atanka (it makes life miserable), Gada (it is produced by multiple causes), Abadha (it causes constant physical or mental discomfort) (a. hru. ni. 1/1). (4)

2. Evidence of Systematic classification based on Pathology of disease is dealt in Ashtangahrudaya (a. hru. ni. 1/8) (5), Madhava nidana (ma. ni. 1/10-13) (6) in the Samprapti (the process of production of disease) discussion section. Here the texts mention about the classification of morbid conditions by number - Sankhya. Permutations and combinations of the disease entities involve- Vikalpa; primary and secondary involvement of disease process by Pradhanya; consideration for severity of the disease based on prodromal- severity of the disease depicted by Bala (strength of the disease) and disease development based on the timeKala; Among these the classification of morbid conditions by number- Sankhya tries to enumerate possibility of a disease types and subtypes. 


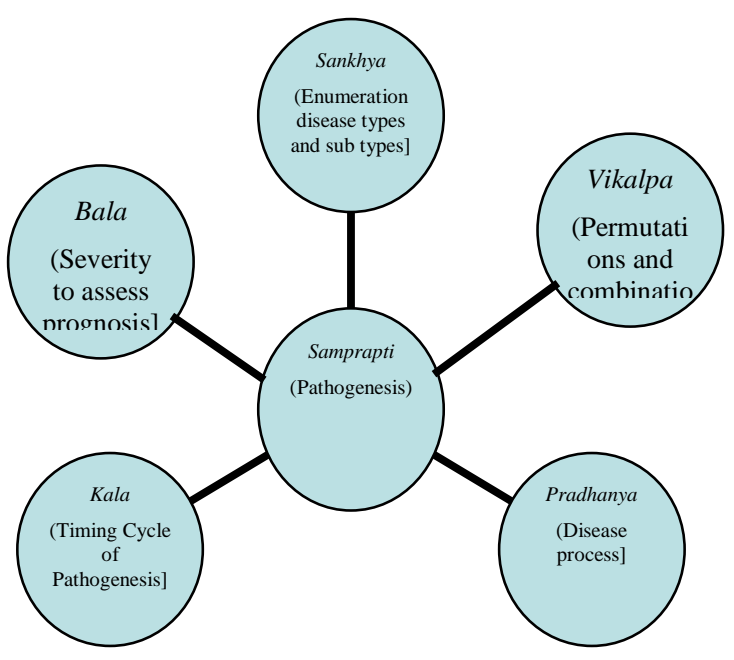

Figure No: 2

\section{The scheme of Classification of diseases according to Ayurveda:}

Ayurveda considers that diseases are innumerable in number, therefore they cannot be kept under a single group or category. It is difficult to adopt any single method for diseases classifications or grouping, to solve problem, diseases and disease conditions are categorized after evaluating several norms. Some of the well adopted schemes are as follows:

1. Disease is only one: Disease as interpreted as pain or discomfort is common to all diseases (ca.su.20/3). (7)

2. Two types: Based on the prognosis i.e Sadhya- managable, Asadya- difficult to manage or incurable. Based on the ease of management the Sadhya conditions are further classified into 1. Sukha sadhya (easily manageable), Krucchra sadhya (manageable with difficulty); the Asadhya ones are classified to 1. Yapya (conditions which need lifelong management), 2. Pratyakhyeya- completely unmanageable (ca. su. 10/9-10; 18/41). (8)

3. Three types: 1. Nija (Caused solely due to derangement of Dosha dhatu i.e.

physiological disturbances/endogenous), 2. Agantuja (Caused due to external factors injuries, accidents/exogenous) 3 . Manasa (psychological imbalance) (ca. su. $11 / 45$; 20/7) (9); this also covers the disease category based on the vitiation of three Doshas (Vata, Pitta and Kapha) (ca. su. 20/3). (10) It provides the basis for two abodes for the disease i.e Sharira (Physiological disturbance physical body) and Manasa (mind).

Another set of classification with three divisions is as follows:

I. Adhyatmika (physical and psychic type, constitutional) 2. Adhibhautika (caused by environment) 3 . Adhidaivika (caused by presumed supernatural agents) the same classification has been elaborated into seven categories in the later classification dealt in Sushruta samhita.

II. Four types: Adhyatmika, Adhibhautika, Adhidaivika and Svabhavika (by nature) is added by (su. su. 24/4). (11) - Which covers conditions like hunger, thirst, old age and death.

III.Based on the possible mode of management i.e medical or surgical diseases are classified in to two categories 1. Shastrasadya - surgically manageable 2. Snehadikriya Sadhyamanageable by medical means viz. by performing Pancakarma etc., (su.su. 24/4). (12)

IV.Seven types of disease: Sushruta samhita nicely sums up all the varieties of morbidity in the following seven categories which is still valid to current times (su.su. 24/4-5). (13)

1. Adibala pravrutta: Disease due to faulty sperm/ovum- indicative of genetic abnormalities.

2. Janmabala pravrutta: Indicative of congenital birth defects, due to improper prenatal/perinatal care. 
3. Doshabala pravrutta: Morbidity due to vitiated dosha (Vata, Pitta, Kapha; Rajoguna and Tamoguna)

4. Sanghatabala pravrutta: Diseases caused by exogenous factors viz., over physical excretion, stress etc.,

5. Kalabala pravrutta: Conditions due to exposure to the vagaries of weather- indicative of seasonal disorders /epidemics.

6. Daivabala pravrutta: Suffering due to divine wrath or other superhuman factors.

7. Svabhavabala pravrutta: Hunger, thirst, old age etc., which are unavoidable and are universal in nature.

Handling exceptions (Ayurvedic approach to handle new disease entity): (14)

Interestingly Ayurveda emphasizes on understanding the nature of the disease, the location of the disease and the causative factor (ca.su.18/44-47). (15) and need not bother about the name, if at all he/she is not aware of it at that time. Naming can follow the treatment, but understanding the underlying pahtophysiology is of utmost importance. Caraka samhita states: a physician need not be ashamed if he is unable to name a particular disease. It is not possible to always assign a name to a disease with certainty. An aggravated dosha may cause different ailments depending on the causative factors and the location o the disease (ca. su. 18/44-47). (16)

Examples of Nosological entities from Ayurvedic Classics:

A. Based on Absolute Doshic involvement:

1. 80 Vataja nanatmaja diseases described in caraka sutrasthana 20/11 (17); Sharngangadhara purvartha (Sharnga. Pu. 7/105-114) (18); a .sam. su. 20/15 (19); a. hru. su. a. ra. 12/53 (20); ka. su. 27/22-33 (21)

2. 40 Pittaja nanatmaja diseases described in ca. su. 20/14 (22);
Sharnga. pu. 7/115-121 (23); a. sam. su. 20/16 (24); a. hru. su. a. ra. 12/53 (25); ka. su. 27/34-40 (26)

3. 20 Kaphaja nanatmaja diseases described in ca. su. 20/17 (27); Sharnga. pu. 7/122-124 (28); a. sam. su. 20/17 (29); a. hru. su. a. ra. 12/53 (30); ka. su. 27/41-46 (31)

4. 10 Raktaja diseases are described in Sharnga. pu. 7/125-126 (32); ka. su. 27/62-65 (33); ca. su. 24/11-17 (34) and ca. su. 28/11-13 (35) also raktaja diseases are found.

B. Based on Dhatu (Tissue Involvement):

The features (equating to the status of individual disease entities) of decrease of dhatu are described in the Sushruta sutra 14/10-12 (36) and Ashtanga hrudayam sutrasthana 11/17-20 (37); The features of increase of dhatu mentioned in Sushruta sutra 14/10-12 (38) and Ashtanga hrudayam sutrasthana 11/8-12 (39)

C. Sroto dushti: Signs of vitiation of various channels of circulations are described in the Caraka, vimana sthana 5/7-8. (40)

D. The eight types of abnormal physical features (constitutions) Ashtanindita purusha - which deptic the gross hormonal disturbances like hirsutism, cretinsm and gigantism etc., described in the Caraka sutrasthana 21/3 chapter. (41)

E. Samanyaja vikara (Conditions pertaining to General medicine (Kayacikitsa): This section includes diseases which generally having the tendency to affect the whole body. The number enumerated from selected Ayurvedic works is a follows:

- Carakasamhita-48 (ca. su. 19/3) (42)

- Madhavanidana-69

- Sharngadharasamhita-65

- Bhavaprakasha-71

- Yogaratnakara-74 Jvaradirogoddesha (43) 
F. Diseases based on Body Location: Shiroroga (diseases of head and scalp), Mukharoga (oral and dental disorders), Karnaroga (ontological conditions),
Netraroga (eye disorders) Nasaroga (diseases of nose). The comparison of number of these diseases from selected Ayurvedic works is as follows:

\begin{tabular}{|c|c|c|c|c|c|}
\hline & $\begin{array}{l}\text { Shiroroga } \\
\text { (diseases of } \\
\text { head- ICD- } \\
\text { C76.0) }\end{array}$ & $\begin{array}{l}\text { Mukharoga } \\
\text { (diseases of } \\
\text { oral cavity- } \\
\text { ICD- } \\
\text { Block:K00- } \\
\text { K14) }\end{array}$ & $\begin{array}{l}\text { Karnaroga } \\
\text { (diseases of } \\
\text { ear-ICD- } \\
\text { Block:H60- } \\
\text { H95) }\end{array}$ & $\begin{array}{l}\text { Netraroga } \\
\text { (diseases of } \\
\text { eye- } \\
\text { Block:H00- } \\
\text { H59) }\end{array}$ & $\begin{array}{l}\text { Nasaroga } \\
\text { (diseases of } \\
\text { nose:J30.0- } \\
\text { J31.0) }\end{array}$ \\
\hline Caraka & $\begin{array}{l}5 \text { (ca. ci. } \\
26 / 118)(44)\end{array}$ & $\begin{array}{l}4(c a . c i .26 \\
/ 119-123) \\
(45)\end{array}$ & $\begin{array}{l}4(\text { ca. ci. } 26 \\
/ 127-128) \\
(46)\end{array}$ & $\begin{array}{l}4 \text { (ca. ci. } \\
26 / 129-131) \\
(47)\end{array}$ & $\begin{array}{l}4(\text { ca.ci. } 26 \\
/ 104-107) \\
(48)\end{array}$ \\
\hline Sushruta & $\begin{array}{l}11(s u . \text { u. } 25- \\
\text { 26) (49) }\end{array}$ & $\begin{array}{l}65 \text { (su. ci. } \\
\text { 22) (50) }\end{array}$ & $\begin{array}{l}28 \text { (su. и. 20) } \\
\text { (51) }\end{array}$ & $\begin{array}{l}76(s u . \text { u. } \\
1 / 29-43)(52)\end{array}$ & $\begin{array}{l}31(\text { su. u. } \\
22,23)(53)\end{array}$ \\
\hline Vagbhata & $\begin{array}{l}9 \text { (a. hru. u. } \\
\text { 23) (54) }\end{array}$ & $\begin{array}{l}75 \text { (a. hru. } \\
\text { u. 21) (55) }\end{array}$ & $\begin{array}{l}25 \text { (a. hru. u. } \\
17,18)(56)\end{array}$ & $\begin{array}{l}94 \text { (a. hru. u. } \\
\text { 8-16) (57) }\end{array}$ & $\begin{array}{l}18 \text { (a. hru. u. } \\
\text { 19) (58) }\end{array}$ \\
\hline Sharangadhara & $\begin{array}{l}10 \text { (sharnga. } \\
\text { pu. } 7 / 149- \\
152)(59)\end{array}$ & $\begin{array}{l}74 \text { (sharnga. } \\
\text { pu. } 7 / 127- \\
133)(60)\end{array}$ & $\begin{array}{l}16 \text { (sharnga. } \\
\text { pu. } 7 / 142- \\
146)(61)\end{array}$ & $\begin{array}{l}94 \text { (sharnga. } \\
\text { pu. } 7 / 153- \\
170)(62)\end{array}$ & $\begin{array}{l}18 \text { (sharnga. } \\
\text { pu. } 7 / 147- \\
148)(63)\end{array}$ \\
\hline Bhavaprakasha & $\begin{array}{l}11 \text { (bha. pra. } \\
\text { ma. 62) (64) }\end{array}$ & $\begin{array}{l}67 \text { (bha. } \\
\text { pra. ma. 66) } \\
(65)\end{array}$ & $\begin{array}{l}28 \text { (bha. pra. } \\
\text { ma. 64) (66) }\end{array}$ & $\begin{array}{l}78 \text { (bha. pra. } \\
\text { ma. 63) (67) }\end{array}$ & $\begin{array}{l}34 \text { (bha. pra. } \\
\text { ma. 65) (68) }\end{array}$ \\
\hline Yogaratnakara & $\begin{array}{l}11 \text { (yo. ra. } \\
\text { shiroroga/4) } \\
(69)\end{array}$ & $\begin{array}{l}67 \text { (yo. ra. } \\
\text { mukha } \\
\text { roga/3-4) } \\
(70)\end{array}$ & $\begin{array}{l}28 \text { (yo. ra. } \\
\text { karnaroga/3- } \\
\text { 5) (71) }\end{array}$ & $\begin{array}{l}76 \text { (yo. ra. } \\
\text { netraroga/3- } \\
\text { 4) (72) }\end{array}$ & $\begin{array}{l}34 \\
\text { (nasaroga/3- } \\
5)(73)\end{array}$ \\
\hline
\end{tabular}

Classification of Morbidity - Biomedical Perspective:

Evolution of Nosography (The systematic description of diseases.) and Nosology in Biomedicine (Pre Hippocratic time to 18th century) (74)

Three Main phases could be distinguished in the evolution of concepts of Nosology.

\section{Pre-Biographic approach:}

Significant feature of primitive or magic medicine and the source of understanding the basis of disease here are completely isolated from the ailing (patient) and by largely depend up on supernatural diagnosis, prognosis and therapy. (75)

\section{Biographic Approach (Natural Medicine):}

"The greatest step ever made in the history of medical thought was made at the very moment when the physician or his forerunner turned to the sick himself as to the source of therapeutically endeavor. This step was made by the Greeks. It marked the birthday of natural medicine based on observation. But here two ways were open. The physician could focus his attention exclusively on the present state of the patient, his sufferings and functional deficiencies. It seems that a healing art based on the study of symptoms alone, was practiced by the school of Knidos. If, however, the physician was driven to an investigation of the genesis of the present state of his patient, he was bound to take a clinical history which is not a simple 
enumeration of events succeeding each other in the march of time, by pure chance: the clinical history springs from causal thought, it is an intelligible whole of connected phenomena succeeding each other with necessity; it still is one of the mightiest instruments of etiology. It is this rational and historical approach which distinguished Hippocratic medicine as practiced by the school of Kos. The historian Thy kidides was believed to have obtained instruction in methods of historical research from the physician Hippocrates". (76)

After reaching this stage of medical thought, the physician no longer was in need of observing movements of the stars, and other completely unrelated events to the patient and also to the disease. This though process has lead to documentation and understanding of systematic natural etiology, diagnosis and prognosis.

To achieve this, the Hippocratic school of thought has laid emphasis on very taking a detailed clinical history and investigations on the broadest scale, listing origin, age, marital state and profession of the patient. If needed, patient's psychophysical development records from, school record, home life, work record, special interests, social activities and views on human life and nature of the patient are recorded in detail. This approach still finds its place in Homoeopathic disciple where great emphasis is made on recording Patients personal biographical account. This approach began during Hippocratic medicine and lasted till $15^{\text {th }}$ century.

\section{Nosography and Pathography Approach:}

When patterns of disease started emerging from careful observation of history of previous illness and the present state of suffering, the focus of understanding shifted from biography to pathography. Pathography indicated the understanding of a selected phase of person's life history distinguished by his illness with all its distinguishing features enabling it to be called as so and so disease. (77)

Once such patterns were recognized and started correlating with other similar ones the new phase of medical history of the patient from a mere biographical one has metamorphosed to a case history. At this stage the physician has passed to nosography. At this juncture the diseases is recognized as an entity which can be independently traced to a persons' health condition even with having may of other details (which was a classical feature of detailed biographical approach). This approach of disease classification allowed physician to understand the underlying pathology and decide the management strategy with better predictability. From this stage onwards the nosographer started outlining scheme of classification of diseases or diagnoses. This phase has begun in early 16th century with the contribution of medical stalworts like Sydenham (England) and continues till $20^{\text {th }}$ century.

Today ( 21 century) we see a clear turn around as it is realized now that just depending up on either of biographic or nosographic approaches cannot offer comprehensive treatment modalities. An exclusive emphasis on nosographic approach and related treatment strategies has lead to lot of misuse especially in the area of Medication. Lack of specificity with respect to individual prescriptions and prevalence of non communicable diseases have forced the researchers of medicines to add another dimension in the form of Genomics. This descipline hase been added make the medicine more personalized and brought back the biographic apporach to health in the modern medical treatment albiet with with more precision. A schematic representation of the scheme of events is depicted in Figure no. 3. 


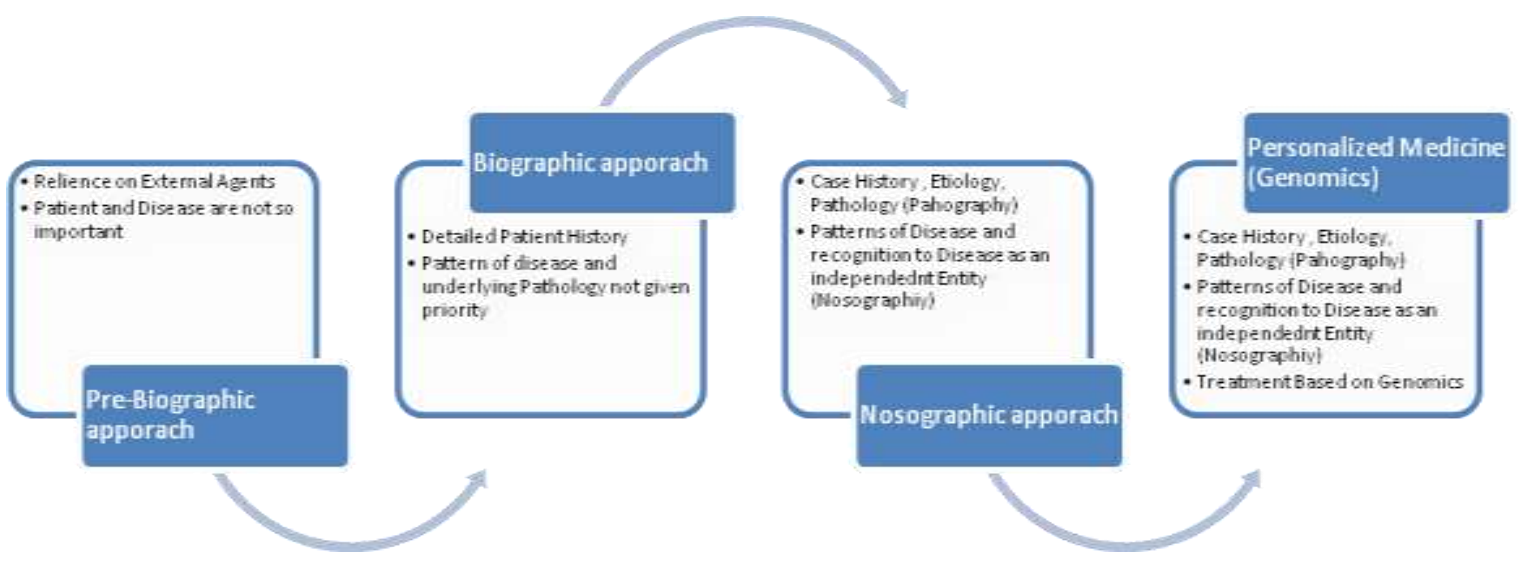

Figure no. 3

\section{Contemporary developments in Disease Classification and Coding (19 century onwards)}

The history of medical coding, or diagnostic coding, dates back to seventeenth-century Great Britain with the London Bills of Mortality. (78)

The following developments in the domain are presented in the following table no. 1

\section{International Classification of Disease:}

The International Classification of Diseases (ICD) is a system developed collaboratively between the World Health Organization (WHO) and 10 international centers so that the medical terms reported by physicians, medical examiners, and coroners on death certificates can be grouped together for statistical purposes. The purpose of the ICD and of WHO sponsorship is to promote international comparability in the collection, classification, processing, and presentation of mortality statistics. Revisions of the ICD are implemented periodically so that the classification reflects advances in medical science. Since 1900, the ICD has been modified about once every 10 years, except for the 20-year interval between the last two revisions, ICD-9 and ICD-10. Effective with deaths occurring in 1999, the United States replaced ICD-9, in use for deaths from 1979 to 1998 , with ICD10. Publications showing mortality data coded under ICD-10 will differ substantially from those under ICD-9 because of changes in coding rules, changes in category names and ICD numbers, and changes in the tabulation lists used to group mortality data. This report will briefly review the history of ICD, highlight major changes in ICD-10, and discuss the statistical impact the revision will have on mortality analysis. (79)

Table No. 1 Important Dates:

\begin{tabular}{|l|l|l|}
\hline Year & Event & Details \\
\hline 1660 & $\begin{array}{l}\text { London Bills of } \\
\text { Mortality }\end{array}$ & John Graunt (80) \\
\hline 1759 & $\begin{array}{l}\text { Genera morborum by } \\
\text { Linneaus (1707-1778) }\end{array}$ & $\begin{array}{l}\text { The life of Sir Charles Linnaeus: knight of the } \\
\text { Swedish Order of the Polar... P.220 By Dietrich } \\
\text { Heinrich Stoever. (81) }\end{array}$ \\
\hline 1763 & Nosologia methodica & $\begin{array}{l}\text { Sir George Knibbs, the eminent Australian } \\
\text { statistician, credited François Bossier de Lacroix } \\
(1706-1777, \text { also known as Sauvages, with the first }\end{array}$ \\
\hline
\end{tabular}




\begin{tabular}{|c|c|c|}
\hline & & attempt to classify diseases systematically. (82) \\
\hline 1785 & $\begin{array}{l}\text { Synopsis nosologiae } \\
\text { methodicae }\end{array}$ & William Cullen (1710-1790) (83) \\
\hline 1837 & $\begin{array}{l}\text { General Register Office } \\
\text { of England and Wales }\end{array}$ & $\begin{array}{l}\text { William Farr (1807-1883) } \\
\text { First medical statistician - General Register Office } \\
\text { of England and Wales - he made the best possible } \\
\text { use of the imperfect classifications of disease } \\
\text { available at the time, and } 2 \text { laboured to secure better } \\
\text { classifications and international uniformity in their } \\
\text { use. (84) }\end{array}$ \\
\hline 1853 & $\begin{array}{l}\text { first International } \\
\text { Statistical Congress, } \\
\text { held in Brussels }\end{array}$ & $\begin{array}{l}\text { The Congress requested William Farr and Marc } \\
\text { d'Espine, of Geneva, to prepare an internationally } \\
\text { applicable, uniform classification of causes of } \\
\text { death. (85) }\end{array}$ \\
\hline 1855 & $\begin{array}{l}\text { Second International } \\
\text { Statistical Congress }\end{array}$ & $\begin{array}{l}\text { Farr and d'Espine submitted two separate lists. } \\
\text { Farr's Classification (Five Groups): epidemic } \\
\text { diseases, constitutional (general) diseases, local } \\
\text { diseases arranged according to anatomical site, } \\
\text { developmental diseases, and diseases that are the } \\
\text { direct result of violence D'Espine classification: } \\
\text { diseases according to their nature (gouty, herpetic, } \\
\text { haematic, etc.). The Congress adopted a } \\
\text { compromise list of } 139 \text { Rubrics. (86) }\end{array}$ \\
\hline 1864 & $\begin{array}{l}\text { classification was } \\
\text { revised in Paris on the } \\
\text { basis of Farr's model }\end{array}$ & \\
\hline $\begin{array}{l}1874,1880 \text {, } \\
\text { and } 1886\end{array}$ & Subsequent revisions & $\begin{array}{l}\text { Note: Although this classification was never } \\
\text { universally accepted, the general arrangement } \\
\text { proposed by Farr, including the principle of } \\
\text { classifying diseases by anatomical site, survived as } \\
\text { the basis of the International List of Causes of } \\
\text { Death. (87) }\end{array}$ \\
\hline 1893 & Bertillon Classification & $\begin{array}{l}\text { International Statistical Institute approved a } \\
\text { standardized system for classifying deaths. List was } \\
\text { prepared by a Paris statistician, Jacque Bertillon } \\
\text { (1851-1922, and was called the Bertillon } \\
\text { Classification By 1900, } 26 \text { countries had } \\
\text { implemented the Bertillon Classification. (88) }\end{array}$ \\
\hline 1898 & & $\begin{array}{l}\text { American Public Health Association, at its meeting } \\
\text { in Ottawa, Canada, recommended the adoption of } \\
\text { the Bertillon Classification by registrars of Canada, } \\
\text { Mexico, and the United States of America. The } \\
\text { Association further suggested that the classification } \\
\text { should be revised every ten years. (89) }\end{array}$ \\
\hline 1899 & $\begin{array}{l}\text { meeting of the } \\
\text { International Statistical } \\
\text { Institute at Christiania }\end{array}$ & $\begin{array}{l}\text { Bertillon presented a report on the progress of the } \\
\text { classification, including the recommendations of } \\
\text { the American Public Health Association for } \\
\text { decennial revisions. (90) }\end{array}$ \\
\hline August & first International & Delegates from 26 countries attended this \\
\hline
\end{tabular}




\begin{tabular}{|c|c|c|}
\hline 1900 & $\begin{array}{l}\text { Conference for the } \\
\text { Revision of the } \\
\text { Bertillon or } \\
\text { International List of } \\
\text { Causes of Death }\end{array}$ & $\begin{array}{l}\text { Conference. A detailed classification of causes of } \\
\text { death consisting of } 179 \text { groups and an abridged } \\
\text { classification of } 35 \text { groups were adopted on } 21 \\
\text { August } 1900 \text {. The desirability of decennial } \\
\text { revisions was recognized, and the French } \\
\text { Government was requested to call the next meeting } \\
\text { in } 1910 \text {. In fact the next conference was held in } \\
1909 \text {, and the Government of France called } \\
\text { succeeding conferences in } 1920,1929 \text {, and } 1938 \text {. } \\
\text { (91) }\end{array}$ \\
\hline 1923 & & $\begin{array}{l}\text { International Statistical Institute, Michel Huber, } \\
\text { Bertillon's successor in France, recognized this lack } \\
\text { of leadership and introduced a resolution for the } \\
\text { International Statistical Institute to renew its stand } \\
\text { of } 1893 \text { in regard to the International Classification } \\
\text { of Causes of Death and to cooperate with other } \\
\text { international organizations in preparation for } \\
\text { subsequent revisions. (92) }\end{array}$ \\
\hline 1928 & $\begin{array}{l}\text { Study on "Expansion of } \\
\text { Bertillon Classification" }\end{array}$ & $\begin{array}{l}\text { Study sponsored by the Health Organization of the } \\
\text { League of Nation discussed how the Bertillon } \\
\text { Classification could be expanded to include the } \\
\text { tracking of diseases. (93) }\end{array}$ \\
\hline 1928 & $\begin{array}{l}\text { Commission of } \\
\text { Statistical Experts }\end{array}$ & $\begin{array}{l}\text { E. Roesle, Chief of the Medical Statistical Service } \\
\text { of the German Health Bureau and a member of the } \\
\text { Commission of Expert Statisticians, prepared a } \\
\text { monograph that listed the expansion in the rubrics } \\
\text { of the } 1920 \text { International List of Causes of Death } \\
\text { that would be required if the classification was to be } \\
\text { used in the tabulation of statistics of morbidity. (94) }\end{array}$ \\
\hline 1936 & $\begin{array}{l}\text { A Standard Morbidity } \\
\text { Code was prepared by } \\
\text { the Dominion } \\
\text { Council of Health of } \\
\text { Canada. }\end{array}$ & $\begin{array}{l}\text { other classifications } \\
\text { The main subdivisions of this code represented the } \\
\text { eighteen chapters of the } 1929 \text { Revision of the } \\
\text { International List of Causes of Death, and these } \\
\text { were subdivided into some } 380 \text { specific disease } \\
\text { categories. (95) }\end{array}$ \\
\hline $\begin{array}{l}\text { October } \\
1938\end{array}$ & $\begin{array}{l}\text { Fifth Decennial } \\
\text { Revision Conference by } \\
\text { the Government of } \\
\text { France and was held in } \\
\text { Paris. }\end{array}$ & $\begin{array}{l}\text { The Conference approved three lists: a detailed list } \\
\text { of } 200 \text { titles, an intermediate list of } 87 \text { titles and an } \\
\text { abridged list of } 44 \text { titles. (96) }\end{array}$ \\
\hline 1942 & $\begin{array}{l}\text { Committee on Hospital } \\
\text { Morbidity Statistics of } \\
\text { the Medical Research } \\
\text { Council was created in } \\
\text { UK to A provisional } \\
\text { classification of } \\
\text { diseases and injuries } \\
\text { for use in compiling } \\
\text { morbidity statistics. }\end{array}$ & \\
\hline
\end{tabular}




\begin{tabular}{|c|c|c|}
\hline 1944 & $\begin{array}{l}\text { Provisional } \\
\text { classifications of } \\
\text { diseases and injuries } \\
\text { were published in both } \\
\text { the United Kingdom } \\
\text { and the United States of } \\
\text { America for use in the } \\
\text { tabulation of morbidity } \\
\text { statistics. }\end{array}$ & \\
\hline 1944. & $\begin{array}{l}\text { The Manual for coding } \\
\text { causes of illness } \\
\text { according to a } \\
\text { diagnosis code for } \\
\text { tabulating morbidity } \\
\text { statistics, consisting of } \\
\text { the diagnosis code, a } \\
\text { tabular list of } \\
\text { inclusions, and an } \\
\text { alphabetical index. }\end{array}$ & \\
\hline 1945 & $\begin{array}{l}\text { Committee on Joint } \\
\text { Causes of Death under } \\
\text { the chairmanship of } \\
\text { Lowell J. Reed, } \\
\text { Professor of } \\
\text { Biostatistics at Johns } \\
\text { Hopkins University. }\end{array}$ & $\begin{array}{l}\text { Proposed single list of conditions instead of } \\
\text { separate ones for morbidity and death. }\end{array}$ \\
\hline 1946 & $\begin{array}{l}\text { Sixth Revision of the } \\
\text { International Lists }\end{array}$ & $\begin{array}{l}\text { International Health Conference held in New York } \\
\text { City entrusted the Interim Commission of the } \\
\text { World Health Organization }\end{array}$ \\
\hline $\begin{array}{l}26 \text { to } 30 \\
\text { April } 1948\end{array}$ & $\begin{array}{l}\text { International } \\
\text { Conference for the } \\
\text { Sixth Revision of the } \\
\text { International Lists of } \\
\text { Diseases and Causes of } \\
\text { Death. }\end{array}$ & \\
\hline 1948 & $\begin{array}{l}\text { the First World Health } \\
\text { Assembly endorsed the } \\
\text { report of the Sixth } \\
\text { Revision Conference } \\
\text { and adopted World } \\
\text { Health Organization } \\
\text { Regulations No. 1, } \\
\text { prepared on the basis of } \\
\text { the recommendations of } \\
\text { the Conference. }\end{array}$ & $\begin{array}{l}\text { Manual of the International Statistical } \\
\text { Classification of Diseases, Injuries, and Causes of } \\
\text { Death; The Manual consisted of two volumes, } \\
\text { Volume } 2 \text { being an alphabetical index of diagnostic } \\
\text { terms coded to the appropriate categories. }\end{array}$ \\
\hline 1949 & $\begin{array}{l}\text { The Manual of the } \\
\text { International } \\
\text { Classification of } \\
\text { Diseases, Injuries and }\end{array}$ & $\begin{array}{l}\text { World Health Organization (WHO) realized the } \\
\text { idea of enacting a system for tracking mortality as } \\
\text { well as causes of diseases on a global basis. (97) }\end{array}$ \\
\hline
\end{tabular}




\begin{tabular}{|c|c|c|}
\hline & Causes of Death (ICD) & \\
\hline $\begin{array}{l}\text { February } \\
1955\end{array}$ & $\begin{array}{l}\text { The International } \\
\text { Conference for the } \\
\text { Seventh Revision of the } \\
\text { International } \\
\text { Classification of } \\
\text { Diseases was held in } \\
\text { Paris under the auspices } \\
\text { of WHO. }\end{array}$ & $\begin{array}{l}\text { this revision was limited to essential changes and } \\
\text { amendments of errors and inconsistencies }\end{array}$ \\
\hline $\begin{array}{l}6 \text { to } 12 \text { July } \\
1965\end{array}$ & $\begin{array}{l}\text { The Eighth Revision } \\
\text { Conference convened } \\
\text { by WHO met in Geneva }\end{array}$ & $\begin{array}{l}\text { During the years that the Seventh and Eighth } \\
\text { Revisions of the ICD were in force, the use of the } \\
\text { ICD for indexing hospital medical records } \\
\text { increased rapidly and some countries prepared } \\
\text { national adaptations which provided the additional } \\
\text { detail needed for this application of the ICD. }\end{array}$ \\
\hline $\begin{array}{l}30 \\
\text { September } \\
\text { to } 6 \text { October } \\
1975\end{array}$ & $\begin{array}{l}\text { The International } \\
\text { Conference for the } \\
\text { Ninth Revision of the } \\
\text { International } \\
\text { Classification of } \\
\text { Diseases, convened by } \\
\text { WHO, met in Geneva }\end{array}$ & $\begin{array}{l}\text { The final proposals presented to and accepted by } \\
\text { the Conference retained the basic structure of the } \\
\text { ICD, although with much additional detail at the } \\
\text { level of the four-digit subcategories, and some } \\
\text { optional five-digit subdivisions. For the benefit of } \\
\text { users not requiring such detail, care was taken to } \\
\text { ensure that the categories at the three-digit level } \\
\text { were appropriate. (dagger and asterisk system) } \\
\text { Classifying diagnostic statements, including } \\
\text { information about both an underlying general } \\
\text { disease and a manifestation in a particular organ or } \\
\text { site. }\end{array}$ \\
\hline 1989 & Tenth Revision & \\
\hline 1993 & $\begin{array}{l}\text { ICD-10 being in use } \\
\text { from this period }\end{array}$ & \\
\hline $\begin{array}{l}\text { October 1, } \\
2013\end{array}$ & & $\begin{array}{l}\text { target date for full execution of ICD-10-PCS, which } \\
\text { is the American version of the new coding. }\end{array}$ \\
\hline Road ahead & $11^{\text {th }}$ Revision (98) & $\begin{array}{l}\text { To produce an international standard for } \\
\text { information on TM that is ready for electronic } \\
\text { health records and that will serve as a standard for } \\
\text { scientific comparability and communication. } \\
\text { Deliverables: } \\
\text { 1. International Classification of Traditional } \\
\text { Medicine; 2. International Standard Terminologies } \\
\text { of Traditional Medicine; 3. A web portal that links } \\
\text { the TM classification and TM terminologies to the } \\
\text { WHO-FIC }\end{array}$ \\
\hline
\end{tabular}

Note: The Twenty-ninth World Health Assembly, noting the recommendations of the International Conference for the Ninth Revision of the International Classification of Diseases, approved the publication, for trial purposes, of supplementary classifications of Impairments and Handicaps and of Procedures in Medicine as supplements to, but not as integral parts of, the International Classification of Diseases. 
Designation Years in Effect: (99)

Table No 2: Types of medical coding: Different types of medical coding systems available are enlisted

\begin{tabular}{|l|l|}
\hline ICD-1 & $1900-1909$ \\
\hline ICD-2 & $1910-1920$ \\
\hline ICD-3 & $1921-1929$ \\
\hline ICD-4 & $1930-1938$ \\
\hline ICD-5 & $1939-1948$ \\
\hline ICD-6 & $1949-1957$ \\
\hline ICD-7 & $1958-1967$ \\
\hline ICDA-8 (adapted) & $1968-1978$ \\
\hline ICD-9 & $1979-1998$ \\
\hline ICD-10 & $1999-$ ongoing \\
\hline
\end{tabular}

Table No. 3: current medical classifications in practice

\begin{tabular}{|c|c|}
\hline Medical coding method & Details \\
\hline $\begin{array}{l}\text { Current Procedural Terminology (CPT) \& } \\
\text { Healthcare Common Procedure Coding } \\
\text { System (HCPCS) }\end{array}$ & $\begin{array}{l}\text { CPT was initially developed by the American } \\
\text { Medical Association back in } 1966 \text {. CPT } \\
\text { codes are updated on an annual basis. } \\
\text { HCPCS codes have two tiers of coding. } \\
\text { The HCPCS is the coding system that is used } \\
\text { for outpatient procedures and doctor services. } \\
\text { The HCPCS has two levels of coding. Level I } \\
\text { is based on the AMA's CPT system. Level II } \\
\text { HCPCS codes are used by medical suppliers, } \\
\text { ambulance services or medical equipment } \\
\text { vendors. }\end{array}$ \\
\hline \multicolumn{2}{|l|}{ International Classification of Diseases (ICD) } \\
\hline $\begin{array}{l}\text { International Classification of Diseases, } \\
\text { Clinical Modification (ICD-9-CM) }\end{array}$ & $\begin{array}{l}\text { It is the uniformed system for gathering } \\
\text { information regarding inpatient procedures in } \\
\text { hospitals. (100) }\end{array}$ \\
\hline \multicolumn{2}{|l|}{$\begin{array}{l}\text { The International Classification of } \\
\text { Functioning, Disability and Health (ICF). } \\
\text { (101) }\end{array}$} \\
\hline The Diagnosis Related Groups (DRG) & $\begin{array}{l}\text { An effort to gain uniformity in the area of } \\
\text { diagnostics }\end{array}$ \\
\hline \multicolumn{2}{|l|}{$\begin{array}{l}\text { The Code on Dental Procedures and } \\
\text { Nomenclature (CDT). (102) }\end{array}$} \\
\hline \multicolumn{2}{|l|}{$\begin{array}{l}\text { Statistical Manual of Mental Disorders } \\
\text { (DSM-IV-TR) (103) }\end{array}$} \\
\hline National Drug Codes (NDC) (104) & $\begin{array}{l}\text { It has been instrumental in developing } \\
\text { consistency and standardization of } \\
\text { prescriptions drugs. }\end{array}$ \\
\hline
\end{tabular}




\section{Developments in Ayurveda ontology:}

Madhavanidana (premier book on

Disease classification in Ayurveda) and its nosological contributions:

\section{The grouping of diseases in tune with Ashtanga ayurveda in}

Meulenbeld has postulated that "Madhavanidana (Roavinishcaya) presents the classification of disease in compliance with six of Ashtangas excluding Rasayana and Vajikarana" (105). The arrangement the groups are as follows:

\begin{tabular}{|l|l|}
\hline $\begin{array}{l}\text { Kayacikitsa (General } \\
\text { medicine) }\end{array}$ & $\begin{array}{l}\text { chapters 2-19, } \\
22-37,49-54)\end{array}$ \\
\hline $\begin{array}{l}\text { Bhutavidya (Possession } \\
\text { and altered psychology) }\end{array}$ & chapters 20- \\
\hline Shalya (Surgery) & $\begin{array}{l}\text { chapters 38- } \\
38 \text { and 55 }\end{array}$ \\
\hline $\begin{array}{l}\text { Shalakya (Ear, Nose and } \\
\text { Throat) }\end{array}$ & $\begin{array}{l}\text { chapters 56- } \\
60\end{array}$ \\
\hline $\begin{array}{l}\text { Kaumarabhrutya (Mother } \\
\text { and Child care) }\end{array}$ & chapters 61- \\
\hline Agadatantra (Toxicology) & chapters 69 \\
\hline
\end{tabular}

\section{Madhavanidana's unique chapters} (106)

- Daha (A syndrome characterized by a burning sensation; ma. ni. 19 (107); ICD- F45.3)

- Nadivrana (Fistulas; ma. ni. 45 (108); ICD-K60.3-K60.5)

- Upadamsha (Affections of the male member; ma. ni. 47 (109); ICDBolck:A50-A64)

- Visarpa (Erysipelas; ma. ni. 52 (110); ICD-Bolck:L00-L08)

- Asrugdara (Menorrhagia and metrorrhagia; ma. ni. 61 (111); ICDN92.4)

- Stanaroga (Diseases of the mammary glands; ma. ni. 66 (112); ICD-N60N64-2)

3. Madhavanidana's new clusters (113).

- Nidra (excessive sleepiness-ICDG47.1), Tandra (Drowsiness-ICDR40.0), Murcha (Syncope-ICD- R55) and Sanyasa (Coma-17; ICD- R40.2. ma. ni. 17) Page no: 200
- Anaha (Distension of abdomen due to obstruction to passage of urine and stools- ICD- R14) is described along with Udavarta (Upward movement of gases- ICD- R14; ma. ni. 27) (114)

4. Madhavanidana's addition of new disease entities: (115); Madhavanidana has added new diseases which were not described in earlier texts or were just mentioned sketchily. These innovations became highly influential and were almost universally acknowledge by later writers. Disorders recognized as independent entities for the first time by Madhava are

- Shula (piercing, colic-like pain-ICDR10-10.4; ma. ni. 26) (116)

- Visphota (diseases in which vesicles or blisters appear-ICD- T14.0; ma. ni. 53) (117)

- Amavata (Often equated with rheumatoid arthritis-Block:ICDM60-M63; ma. ni. 25) (118) - Note: Harita samhita (III.21) also described it in its own way

- Parinamashula (a type of Shula manifesting itself during the digestion of food- ICD- K26-K28) and Annadravashula (which may appear during the digestive process or precede or follow it- ICD- K26-K28; ma. ni. 26/15-22) (119)

- Medoroga (obesity-Block:ICD- E65E68; ma. ni. 34) (120)

- Sitapitta (Urticaria-Block:ICD- L50L54; ma. ni. 50) (121) - three disorders closely related to Shitapitta, Kotha (an exanthematous, itching eruption- Block:ICD- L50-L54;), Utkotha (a special form of urticariaBlock:ICD- L50-L54;) are dealt in the same chapter.

- Amlapitta (Corresponding to a dyspepsia accompanied by vomiting and diarrhea or spitting or bloodICD- K31.8-K31.9; ma. ni. 51) (122); elsewhere in other Samhitas this was considered as a symptom, but in Madhava nidana it gets the status of a separate disease. In this case it seems 
that Harita samhita has been influenced by this section and included it and the context dealing with this section in kashyapa samhita appears to be the original (ka. khi.16). (123)

- Mashurika (smallpox, chiken pox and other infectious, eruptive fevers-ICDB01-B05) (ma. ni. 54) (124)

- Shukaradamshtraka (suppuration lesion of the skin with burning sensation of penis-ICD-C60.9) ( $m a$. ni. madhu. 55/55) (125)

- Khuncana (Blepharospasm- ICDG24.5) (ma.ni. 59/96) (126)

- Pakshmashata (Madarosis/Blepharitis-ICD- H02) (ma. ni. 59/99) (127)

- Yonikanda (Tuberous swelling in the vagina-ICD- N84- N84.9) (ma. ni. 63) (128)

New diseases described by other texts: Sharngadhara Samhita: (13 A.D)

The description of 4 types of Amavata (Sharnga. pu. 7/41) (129) and Snayuka krimi roga (Sharnga. pu. 7/18) (130) has been recognized for the first time.

\section{Bhavaprakasha: (16 A.D)}

New diseases like Mutratisara (bha. pra. ma. 69/12) (131) (excess urination-ICD- R35- R36), Shitala (bha. pra. ma. 60) (132) (small pox-ICD- B03) added and a venereal disease Phiranga roga (bha. pra. ma. 59) (133) (SyphilisBlock:ICD- A65-A69) described as a separate chapter.

Apart from Udararoga (Abdominal diseases-Block:ICD- R10-R19), separate chapters has been mentioned to liver and spleen diseases in the Plihadhikara (bha. pra. ma. 33). (134)

Separated chapters of Vata (bha. pra. ma. 24) (135), Pitta (bh. ma. 27), Kapha (bha. pra. ma. 28) diseases, Medoroga (obesity- Block:ICD- E65E68)(bha. pra. ma. 39) (136), Karshya roga (Tuberculosis-Block:ICD-A15-A19) (bha. pra. ma. 40) (137), Somaroga (polyuria in women-ICD-R35) (bha. pra. ma. 69) (138), Upadamsha (chancroidICD-Bolck:A50-A64) (bha. pra. ma. 51) (139), Snayu roga (guinea worm infestation-ICD- B72) (bha. pra. ma. 57) (140) has been described.

Yoga ratnakara: (18 A.D) (141)

Vyavayi shosha (consumption due to excessive coitus- Block:ICD-A15-A19), Kuranda (Inguinal hernia-ICD- K40) disease and its treatment also described.

Sadyovrana (suddenly caused wound-ICD-T14), Agnidagdha cikitsa (Burns-Block:ICD- T20-T32), Bhagna vrana (Fracture with ulcer formationICD-M86), Yauvana pithika (Acne vulgaris-ICD-L70.0), Nyaccha (Naevus/mole-ICD-I78.1) and Vyanga (hyper pigmentation of skin-ICD-L81.4), Padmini kantaka (Papilloma of skin- ICDB97), Mudha garbha (Mal-presentation of the foetus- ICD- O32- O32.9)- these diseases are described in separate chapters in detail.

Bhaishajyaratnavali: (19 A.D) (142)

Detail description of the diseases like Urustambha (Stiffness in thigh muscles-ICD- G82.1) (28 ch.), Pramehapidaka (Diabetic carbuncle-ICDL02- L02.9 (38 ch.), Vruddhi (HydroceleICD-N43- N43.3) (43 ch.), Galaganda (Goiter-ICD- E01-E05) (44 ch.), Sadyovrana suddenly caused wound-ICDT14 (48 ch.), Udardashitapittakotha (Urticaria-Block:ICD- L50-L54; (55 ch.), Visarpa (Erysipelas-ICD- A46) (57 ch.), Visphota (Blister- ICD- T14.0) (58 ch.), Masurika (Eruption of lentil-shaped pustules-ICD- L27) (59 ch.), Pradara (Leukorrhoea-ICD-N89.8) (66 ch.), Garbhini (pregnancy-ICD- O00.0- O30.8) (68 ch.), Sutika (Delivered woman - O80O84 ) (69 ch.), Stana (Disorders of breast; Block:CD- N60-N64) (70 ch.), Bala (disorders of infant and child- ICD-Z76.2) (71 ch.) separate chapters.

Separate chapters with treatment of Amashayaroga (diseases of stomach and duodenum-Block:ICD-K20-K31) (76 ch.), 
Gadodvega (78 ch.), Tandavaroga (81 ch.), Snayuroga (82 ch.), Khalitya (Alopecia-ICD-L65.9) (83 ch.), Khanja (Limping-ICD-I73.9) (84 ch.), Urastoya (Pleural effusion-ICD- J90) (85 ch.), Bahumutra (Polyuria-ICD- R35) (86 ch.), Somaroga, Mutratisara (Polyuria in women-ICD-R35-R36) (87 ch.), Shukrameha (88 ch.), Aupasargika meha (89 ch.), Ojomeha (AIDS-ICD-B24) (90 ch.), Lasikameha (91 ch.), Dhvajabhanga (92 ch.), Vrukkaroga (renal disorders-ICDN00-N20.0) (93 ch.), Klomaroga (Pancreatic disorders-Block:ICD-K80K87) (94 ch.), Phiranga (SyphilisBlock:ICD-A65-A69) (95 ch.), Snayukaroga (Guinea worm infestationICD- B72) (96 ch.), Shirshamburoga (Hydrocephalus-ICD-G91) (98 ch.), Mastishkavepana (Cerebral contusionICD-S00) (99 ch.), Mastishkacayapcaya (Cerebral palsy-ICD-G80)(100 ch.), Mastishkaroga (brain related disordersICD- G80- G81) (101 ch.), Amshughata (Heatstroke and sunstroke-ICD-T67.0) (102 ch.), Yoshapatantraka (HysteriaICD-F44) (103 ch.), Yonikandu (VaginitisICD-N76.1) (104 ch.), Andadhara roga (Pain and other conditions associated with female genital organs and menstrual cycleICD-N94)(105 ch.), Apamumurshu (106 ch.).

\section{Interdisciplinary Adaptation of Concept of Medical Codes - An alliance between Biomedicine and Traditional medicines for better Case records.}

Mainstreaming of TM -

Traditional Medicine from various countries has always been a priority with World Health Organization. It has been encouraging all the efforts to bring in scientific temper and ethical practice in these systems by promoting research and development on par with Biomedicine. The latest in such effort is considering International Classification of Traditional Medicine, adaptation of ICD like classification to TM which are expected to facilitate uniform case recording and possibly implementation of Electronic Health records. As of now TCMTraditional Chinese Medicine and Korea medicine have been benefited from these initiatives. The widely practiced Indian Systems of Medicine Ayurveda, Siddha and Unani have are now considered for standardization of terminologies. World health organization (WHO) Agreement for Performance of Work (APW) has been taken up at National Institutes of Ayurveda, Unani and Siddha to come up with plausible standard clinical and non clinical terminologies to pave way for further coding. (143) Apart from these Central council for Research in Ayurveda Sciences (CCRAS) has initiated two projects 1. AYUSH Research Portal 2. Integrated Clinical Decision Support System (ICDSS) which are using ICD-10 codes and corresponding diagnosis with plausible Ayurveda/Siddha/Unani disease names.

\section{Conclusion:}

Health is a matter of Individual, Familial and State concern. No societies can survive and exist in harmony without having a proper health care system in place. Today we have a fairly evolved health care system across the world, but the status of its implementation is very diverse. There is a huge division in terms of availability of health care infrastructure between developed, underdeveloped countries and sometimes between two places in a single country itself. Use of rational methods, harmony with respect to use of standardized medical terms is a level player to communicate the ground realities and will help bridge this gap. All the efforts to develop and implement the usage of Medical Coding irrespective of medical discipline are the need of hour. Having developed the robust systems like International Classification of Disease 
(ICD) and heading for implementation of its latest $10^{\text {th }}$ revision, it is time for all Indigenous systems to catch up and standardize their own terminology (ICD11). This effort will demonstrate the strength of AYUSH systems will fetch wider acceptance and long-term sustenance.

\section{Acknowledgement:}

\section{List of abbreviations:}

\section{Abbreviation}

ca. su.

ca. $c i$.

su. su.

su. ci.

su. $u$.

a. hru. su. a. ra

a. hru. ni.

a. hru. u.

sharnga. pu.

sha. pu.

bha. pra. ma.

yo. ra.

ma. ni. madhu.

ka. su.

ka. khi.

I.C.D

Ch. ma. $n i$.
Sincere thanks to Dr. Rakesh Sarwal, I.A.S (Joint secretary - AYUSH Dep, MoH \& FW, GOI, 2010-2011), Adviser-Health, Planning Commission of India and Dr. Ramesh Babu Devella, Director General, Central Council for Research in Ayurvedic Sciences (CCRAS), India for their encouragement and support.

\section{Expansion}

Carakasamhita sutrasthanam

Carakasamhita cikitsasthanam

Sushrutasamhita sutrasthanam

Sushrutasamhita cikitsasthanam

Sushrutasamhita uttaratantram

Ashtamgahrudaya sutrasthana, ayurveda rasayana vakya

Ashtamgahrudaya nidanasthanam

Ashtamgahrudaya uttarasthanam

Sharngadharasamhita purva khanda

Sharngadharasamhita madhyama khanda

Bhavaprakashah madhyama khanda

Yogaratnakara

Madhavanidanam

Madhavanidana, madhukosha vakya

Kashyapasamhita sutrasthanam

Kashyapasamhita khilasthanam

International Classification of Disease

Chapter

\section{References:}

1. http://en.wikipedia.org/wiki/ Disease. accessed on 10 September 2011

2. http://en.wikipedia.org/wiki/

Medical_coding accessed on 10 September 2011

3. Charaka Samhita, Translation: Ram Karan Sharma \& Vaidya Bhagwan Dash, Chowkambha Sanskrit Series office, Varanasi. Reprint: 2008; VolI; Page no: 25

4. Vagbhata's Astanga Hrdayam, Translation: Prof. K. R. Srikantha Murthy, Chowkhamba Krishnadas Academy, Varanasi. Reprint: 2010; Vol- II; Page no: 3

5. Ibid; Page no: 6

6. Madhavanidanam of Sri Madhavakara, Translation: Dr. P. Himasagara Chandra Murthy, Chowkhamba Sanskrit Series Office, Varanasi. Print: 2006, Vol-1; Page No: 25-26

7. Charaka Samhita, Translation:Ram Karan Sharma \& Vaidya Bhagwan Dash, Chowkambha Sanskrit Series office, Varanasi. Reprint: 2008; VolI; Page no: 360

8. Ibid; Page no: $196-197$ and 344

9. Ibid; Page no: 226-227 and 361

10. Ibid; Page no: 360

11. Prof. G.D. Singhal \& Colleagues, Susruta-Samhita Ancient Indian Surgery, Chaukhamba Sanskrit 
Pratishthan, Delhi. Reprint: 2007:

Vol: 1; Page no: 214

12. Ibid;

13. Ibid; Page no: 214-215

14. Dr. S.R.Sudarshan, A descriptive glossary of Diseases in Ayurveda, Sadguru publications, A division of Indian Books Centre, Delhi, India, 2002 Introduction

15. Charaka Samhita, Translation: Ram Karan Sharma \& Vaidya Bhagwan Dash, Chowkambha Sanskrit Series office, Varanasi. Reprint: 2008; VolI; Page no: 345

16. Ibid;

17. Ibid; Page no: 363

18. Sarngadhar-Samhita, Translation: Prof. K.R. Srikanta Murthy, Chaukhambha Orientalia, Varanasi. Edition: 1984; Page no: 40

19. Ashtanga samgraha of Vagbhata, Translation: Prof. K.R. Srikantha Murthy, Chaukhambha Orientalia, Varanasi. Reprint: 2007; Vol-1; Page no: 376-377

20. E-book Ashtanga hrudayam, Institute of Ayurveda and Integrative Medicine (IAIM), FRLHT, Bangalore.

21. Kasayapa-Samhita or Vrddhajivakiya Tantra, Prof. (Km.) P.V. Tewari, Chaukhamba Visvabharati, Varanasi. Reprint 2002; Page no: 68

22. Charaka Samhita, Ram Karan Sharma \& Vaidya Bhagwan Dash, Chowkambha Sanskrit Series office, Varanasi. Reprint: 2008; Vol- I; Page no: 367

23. Sarngadhar-Samhita, Prof. K.R. Srikanta Murthy, Chaukhambha Orientalia, Varanasi. Edition: 1984; Page no: 41

24. Ashtanga samgraha of Vagbhata, Translation: Prof. K.R. Srikantha Murthy, Chaukhambha Orientalia, Varanasi. Reprint: 2007; Vol-1; Page no: 377

25. E-book Ashtanga hrudayam, Institute of Ayurveda and Integrative
Medicine

(IAIM),

FRLHT,

Bangalore.

26. Kasayapa-Samhita or Vrddhajivakiya Tantra, Prof. (Km.) P.V. Tewari, Chaukhamba Visvabharati, Varanasi. Reprint 2002; Page no: 69-70

27. Charaka Samhita, Ram Karan Sharma \& Vaidya Bhagwan Dash, Chowkambha Sanskrit Series office, Varanasi. Reprint: 2008; Vol- I; Page no: 370

28. Sarngadhar-Samhita, Translation: Prof. K.R. Srikanta Murthy, Chaukhambha Orientalia, Varanasi. Edition: 1984; Page no: 41

29. Ashtanga samgraha of Vagbhata, Translation: Prof. K.R. Srikantha Murthy, Chaukhambha Orientalia, Varanasi. Reprint: 2007; Vol-1; Page no: 377

30. E-book Ashtanga hrudayam, Institute of Ayurveda and Integrative Medicine (IAIM), FRLHT, Bangalore.

31. Kasayapa-Samhita or Vrddhajivakiya Tantra, Translation: Prof. (Km.) P.V. Tewari, Chaukhamba Visvabharati, Varanasi. Reprint 2002; Page no: 7071

32. Sarngadhar-Samhita, Translation: Prof. K.R. Srikanta Murthy, Chaukhambha Orientalia, Varanasi. Edition: 1984; Page no: 41

33. Kasayapa-Samhita or Vrddhajivakiya Tantra, Translation: Prof. (Km.) P.V. Tewari, Chaukhamba Visvabharati, Varanasi. Reprint 2002; Page no: 73

34. Charaka Samhita, Translation: Ram Karan Sharma \& Vaidya Bhagwan Dash, Chowkambha Sanskrit Series office, Varanasi. Reprint: 2008; VolI; Page no: 405

35. Ibid; Page no: 576

36. Prof. G.D. Singhal \& Colleagues, Susruta-Samhita Ancient Indian Surgery, Chaukhamba Sanskrit Pratishthan, Delhi. Reprint: 2007: Vol: 1; Page no: 117-118 
37. Vagbhata's Astanga Hrdayam, Translation: Prof. K. R. Srikantha Murthy, Chowkhamba Krishnadas Academy, Varanasi. Reprint: 2009; Vol-1; Page no: 158

38. Prof. G.D. Singhal \& Colleagues, Susruta-Samhita Ancient Indian Surgery, Chaukhamba Sanskrit Pratishthan, Delhi. Reprint: 2007: Vol: 1; Page no: 117-118

39. Vagbhata's Astanga Hrdayam, Translation: Prof. K. R. Srikantha Murthy, Chowkhamba Krishnadas Academy, Varanasi. Reprint: 2009; Vol-1; Page no: 144

40. Charaka Samhita, Translation: Ram Karan Sharma \& Vaidya Bhagwan Dash, Chowkambha Sanskrit Series office, Varanasi. Reprint: 2008; Vol2; Page no: 174-175

41. Charaka Samhita, Translation: Ram Karan Sharma \& Vaidya Bhagwan Dash, Chowkambha Sanskrit Series office, Varanasi. Reprint: 2008; VolI; Page no: 374

42. Ibid; Page no: 347

43. Yogaratnakara, Dr. Madham shetty Suresh, The Chowkhamba Sanskrit Series Office, Vanarasi; Edition: 2005; Vol-1; Page no: 225

44. Charaka Samhita, Translation: Ram Karan Sharma \& Vaidya Bhagwan Dash, Chowkambha Sanskrit Series office, Varanasi. Reprint: 2008; Vol4; Page No: 504

45. Ibid; Page No: 505

46. Ibid; Page No: 507-508

47. Ibid; Page No: 508-509

48. Ibid; Page No: 499-500

49. Prof. G.D. Singhal \& Colleagues, Susruta-Samhita Ancient Indian Surgery, Chaukhamba Sanskrit Pratishthan, Delhi. Reprint: 2007: Vol: 3; Page No: 152-162

50. Prof. G.D. Singhal \& Colleagues, Susruta-Samhita Ancient Indian Surgery, Chaukhamba Sanskrit Pratishthan, Delhi. Reprint: 2007: Vol: 2; Page No: 358-369
51. Prof. G.D. Singhal \& Colleagues, Susruta-Samhita Ancient Indian Surgery, Chaukhamba Sanskrit Pratishthan, Delhi. Reprint: 2007: Vol: 3; Page No: 122-125

52. Ibid; Page No: 7-10

53. Ibid; Page No: 136-144

54. Vagbhata's Astanga Hrdayam, Translation: Prof. K. R. Srikantha Murthy, Chowkhamba Krishnadas Academy, Varanasi. Reprint: 2009; Vol-3; Page No: 218-223

55. Ibid; Page No: $184-197$

56. Ibid; Page No: $153-172$

57. Ibid; Page No: 74-154

58. Ibid; Page No: 173-183

59. Sarngadhar-Samhita of Sarangadhara, Translation: Prof. K.R. Srikanta Murthy, Chaukhambha Orientalia, Varanasi. Edition: 1984; Page No: 43

60. Ibid; Page No: 42

61. Ibid; Page No: 43

62. Ibid; Page No: 44-45

63. Ibid; Page No: 43

64. Bhavaprakasa of Bhavamisra, Translation: Dr. Bulusu Sitaram publisher, Chaukhambha Orientalia, Varanasi. Edition: 2010; Page No: 596-603

65. Ibid; Page No: 654-674

66. Ibid; Page No: 638-645

67. Ibid; Page No: 604-637

68. Ibid; Page No: 646-653

69. Yogaratnakara, Translation: Dr. Madham shetty Suresh, The Chowkhamba Sanskrit Series Office, Vanarasi; Edition: 2005; Vol-1; Page No: 1074-1085

70. Ibid; Page No: 1035-1036

71. Ibid; Page No: $1050-1051$

72. Ibid; Page No: $1085-1086$

73. Ibid; Page No: 1062-1074

74. Walther Riese, The conception of Disease (its history, its versions and its Nature, Philosophical Library, New York1953; Page no.86-92

75. Ibid

76. Ibid 
77. Ibid

78. The History of Medical Coding | eHow.com

http://www.ehow.com/about_558136

4_history-medical-

coding.html\#ixzz1TlrZwILd accessed on 15 September 2011

79. Ibid

80. Ibid

81. Ibid

82. Ibid

83. Ibid

84. Ibid

85. Ibid

86. Ibid

87. Ibid

88. Ibid

89. Ibid

90. Ibid

91. Ibid

92. Ibid

93. Ibid

94. http://www.who.int/classifications/ icd/en/HistoryOfICD.pdf - History of the development of the ICD accessed on 18 September 2011

95. Ibid

96. Ibid

97. Ibid

98. https://sites.google.com/site/ whoictm/ accessed on 18 September 2011

99. http://www.cdphe.state.co.us/hs/ briefs/icd10brief.pdf - New International Classification of Diseases (ICD-10), The History and Impact, BRIEF Health Statistics Section, Colarado Department of Public Health and Environment, March 2001 No. 41; accessed on 15 September 2011

100. The History of Medical Coding eHow.com http://www.ehow.com/ about 5581364_history-medicalcoding.html\#ixzz1TlrZwILd accessed on 15 September 2011

101. Ibid

102. Ibid

103. Ibid
104. http://www.who.int/classifications/ icd/en/HistoryOfICD.pdf - History of the development of the ICD accessed on 18 September 2011

105. G.J. Meulenbeld, Madhavas Works on Nidana and Cikitsa, History of Medicine in India (From Antiquity to1000 A.D), INSA, New Delhi; 1992; Page no: 244

106. Ibid

107. Madhavanidanam of Sri Madhavakara, Translation: Dr. P. Himasagara Chandra Murthy, Chowkhamba Sanskrit Series Office, Varanasi. Print: 2006, Vol-1; Page no: 218

108. Dr. G.D. Singhal \& Colleagues, Ayurvedic Clinical Diagnosis Based on Madhava Nidana, Chaukhambha Sanskrit Pratishthan, Delhi; Part-2; Page no: 751

109. Ibid; Page no: 800

110. Ibid; Page no: 843

111. Ibid; Page no: 1057

112. Ibid; Page no: 1107

113. G.J. Meulenbeld, Madhavas Works on Nidana and Cikitsa, History of Medicine in India (From Antiquity to1000 A.D), INSA, New Delhi 1992; Page no: 244

114. Madhavanidanam of Sri

Madhavakara, Translation: Dr. P.

Himasagara Chandra Murthy, Chowkhamba Sanskrit Series Office, Varanasi. Print: 2006, Vol-1; Page no: 200

115. Ibid; Page no: $282-285$

116. G.J. Meulenbeld, Madhavas Works on Nidana and Cikitsa, History of Medicine in India (From Antiquity to1000 A.D), INSA, New Delhi 1992; Page no: 244

117. Madhavanidanam of Sri Madhavakara, Translation: Dr. P. Himasagara Chandra Murthy, Chowkhamba Sanskrit Series Office, Varanasi. Print: 2006, Vol-1; Page no: $275-278$ 
118. Dr. G.D. Singhal \& Colleagues, Ayurvedic Clinical Diagnosis Based on Madhava Nidana, Chaukhambha Sanskrit Pratishthan, Delhi.; Part-2; Page no: 859-864

119. Madhavanidanam of Sri Madhavakara, Translation: Dr. P. Himasagara Chandra Murthy, Chowkhamba Sanskrit Series Office, Varanasi. Print: 2006, Vol-1; Page no: 272

120. Ibid; Page no: 280

121. Dr. G.D. Singhal \& Colleagues, Ayurvedic Clinical Diagnosis Based on Madhava Nidana, Chaukhambha Sanskrit Pratishthan, Delhi.; Part-2; Page no: 593-597

122. Ibid; Page no: $823-825$

123. Ibid; Page no: $831-837$

124. Kasayapa-Samhita or Vrddhajivakiya Tantra, Translation: Prof. (Km.) P.V. Tewari, Chaukhamba Visvabharati, Varanasi. Reprint 2002; Page no: 630-635

125. Dr. G.D. Singhal \& Colleagues, Ayurvedic Clinical Diagnosis Based on Madhava Nidana, Chaukhambha Sanskrit Pratishthan, Delhi.; Part-2; Page no: 871-883

126. Ibid; Page no: 912

127. Ibid; Page no: 1035

128. Ibid; Page no: 1036
129. Ibid; Page no: 1079-1081

130. Sarngadhar-Samhita of Sarangadhara, Translation: Prof. K.R. Srikanta Murthy, Chaukhambha Orientalia, Varanasi. Edition: 1984; Page no: 35

131. Ibid; Page no: 32

132. Bhavaprakasa of Bhavamisra, Translation: Dr. Bulusu Sitaram publishe, Chaukhambha Orientalia, Varanasi. Edition: 2010; Page no: 690

133. Ibid; Page no: 564-573

134. Ibid; Page no: $560-563$

135. Ibid; Page no: $385-387$

136. Ibid; Page no: $263-304$

137. Ibid; Page no: 436-444

138. Ibid; Page no: $445-446$

139. Ibid; Page no: 690

140. Ibid; Page no: 517-522

141. Ibid; Page no: 554-555

142. Yogaratnakara, Translation: Dr. Madham shetty Suresh, The Chowkhamba Sanskrit Series Office, Vanarasi; Vol-1 (2005) \& V01-2 (2008)

143. Govinda Das, Bhashjya Ratnavali, Rev. and Ed., Narendranath Misra, Jagadev Vidyalankar, Haridutt Shastry, Lalchandraji Vaidya, Motilal Banarasi Das, Varanasi, 1884 